\title{
5. The Settlement of the Danes at Tranquebar and Serampore.
}

Dear SIR,-Sir William Hunter, in his "Imperial Gazetteer of India," vol. vi, p. 372 (art. 'India'), says :-“"The first Danish East India Company was formed in 1612, and the second in 1670. The settlements of Tranquebar and Serampur were both founded in 1616, and acquired by the English by purchase from Denmark in 1845." These statements Sir William Hunter repeats verbatim in his "Indian Empire" and "Brief History of the Indian Peoples." Again, in vol. xiii of the "Imperial Gazetteer," p. 340 (art. 'Tranquebar'), we are told that "In 1612 a Danish East India Company was formed at Copenhagen, and in 1616 the first Danish ship arrived in India. The captain, Rodant [sic] Crape, to effect a landing, is said to have wrecked his ship off Tranquebar, at the expense, however, of his crew, who were all murdered. He then contrived to make his way to the Rajá of Tanjore, and obtained Tranquebar for the Danish Company, with land around five miles long and three miles broad. A fort was built, and in 1624 Tranquebar became the property of the King of Denmark, to whom the Company owed money." The above, in an abbreviated form, is copied into Balfour's "Cyclopaedia of India," third ed., vol. iii, p. 921 (art. 'Tranquebar').

I do not know whence Sir William Hunter obtained the information given in the above extracts; but, as it is extremely erroneous, and is in danger of being repeated as authentic by other writers, ${ }^{1}$ I venture to ask you for

1 See, for instances, Birdwood's "Report on the old Records of the India Office," second reprint, 1891, pp. 31 (note), 211, 253 (note). As an example of the unreliable statements of earlier writers on this subject, I may quote the following from Percival's "Account of the Island of Ceylon" (second ed., 1805), p. 28 :- "In 1620 a Danish fleet arrived at Batacolo; but the King of Candy, finding that the ambassador in whom he chiefly confided was dead, and taking offence at some conduct of these newcomers, refused to enter into any league with them, or even to permit them to land. The Danes in consequence were obliged to abandon the enterprise, and to set sail on their return to Europe. Being in want of refreshments, they put into Tranquebar, on the Coromandel coast; and this circumstance gave rise to the first settlement of the Danish colony which has continued there ever since." 
a little space in which to record the main facts connected with the first settlement of the Danes in India.

The first Danish East India Company was formed at Copenhagen in 1616 , a royal patent being granted to it by Christian IV, dated at Anderskov, March 17, 1616, and a large sum of money being advanced to it by the King. While arrangements were in progress for an expedition to the East, under the guidance of Dutch seamen who had entered the Danish service, there appeared on the scene in Copenhagen, in 1617, the ci-devant Dutch under-merchant Marcellis de Boschhouwer, who, after a residence of over three years in Ceylon, now returned to Europe as the plenipotentiary of the King of Ceylon, by whom he had been created 'Migommerale' or 'Migomme Bandar' (correctly Mīgamurāla, Mĩgamubaṇdāra, i.e. Chief or Prince of Negombo). This man, not meeting with the encouragement he anticipated among his fellow-countrymen, had turned to the Danes, and was welcomed by King Christian, who concluded a treaty with him, as Ceylonese ambassador, on March 30, 1618, and in October of the same year granted a large sum of money for the expenses of an expedition to Ceylon. This expedition, consisting of five ships under the command of a Danish noble, Ove Gjedde, set sail on November 29,1618, and arrived at the south-east coast of Ceylon on May 16, 1620. Boschhouwer, who had given great trouble on the voyage, had died in October, 1619 ; and the Kandyan monarch repudiated his credentials as forgeries. Thereupon Gjedde caused Boschhouwer's corpse (which had been embalmed) to be buried without auy ceremony; that of his infant son, however (who had also died on the voyage), was interred with all the respect due to the godchild of King Christian. Boschhouwer's widow (a Sinhalese or a half-caste) was sent up to Kandy, and his property was confiscated by Gjedde. Subsequently one of the Danish ships struck on a rock in Kottiyar Bay and sank. Altogether, so far as Ceylon was concerned, the expedition was a lamentable failure.

Some months previous to the departure of Ove Gjedde's 
fleet, however, Roelant Crape, a Dutch seaman in the Danish service, had sailed (in August, 1618) for Coylon and India as the pioneer of the Danish East India Company. Calling at Ceylon, Crape landed to apprise the King of Kandy of the intended visit of Gjedde; and while he was on shore his officers seized a number of small Portuguese vessels (champagner) laden with rice and areca-nuts. Tidings of this outrage having reached the Portuguese at Jaffnapatam, Andre Botelho da Costa set out with six galleys to chastise the insolence of the interlopers. He found Crape's vessel, the Öresund, lying off Karikal, and forthwith attacked it. In the conflict the Portuguese commander and seven of his men were killed; whilst on the Danish side eight were slain, several were burnt to death, and forty were captured by the Portuguese. The Öresund in attempting to escape was stranded; and Crape and thirteen of his company managed to swim ashore, where they were received graciously by 'Ragnado' (Rāghunātha), the Nāyak Rājā of Tanjore, ${ }^{1}$ who made a concession to the Danes, on certain terms, of the town of Tarangambādi (Tranquebar), with permission to erect a fortress for their defence. These events appear to have taken place in the early part of the year $1620 .^{2}$

Soon after Gjedde's arrival at Ceylon, a messenger from Crape informed him of the above facts; and in September, 1620, Gjedde proceeded to Tranquebar, where, after considerable negotiation, a treaty with the Nāyak was signed, dated November 19, 1620. Having appointed the various officials for the new Danish settlement of Dannisborg, with Crape as chief, Gjedde sailed in February, 1621, for Ceylon, and after a short stay there left, on May 31, for Denmark, where he arrived in February, 1622.

1 T. Venkasami Row, in his "Manual of the District of Tanjore" (1883), p. 754, says, "It does not appear who that Náyak Rája was" ; but the Danish authorities leave no doubt as to his identity.

"Hunter's "Imp. Gaz.," vol. xiii, p. 183 (art. 'India”), says: “Trauquebar settlement, . . . . which the Danes acquired from the Naik Raja of Tanjore in 1620." And yet on page 340 of the same volume we have the erroneous statements that I have quoted above. 
The above is a brief but, I believe, accurate account of the settlement of the Danes at Tranquebar.

With regard to Serampore, curiously enough, the Danish anthorities that $I$ have consulted do not give the exact date when the settlement there took place. In the "Diary of William Hedges" (Hakluyt Society), vol, iii, p. cciv (note), Sir Henry Yule, commenting on the map of 'Bengale' in Valentyn's "Oud en Nieuw Oost-Indien," vol. v, points out an anachronistic and erroneous interpolation of three place-names ${ }^{I}$ on the east bank of the Hughli, one being "Deense Logie" (Danish Factory), which he explains as "the Danish settlement at Serampore, . . . established long after 1664." Hunter's "Imp. Gaz.," vol. xii, p. 318 (art. "Serampur'), says simply "Serampur was formerly a Danish settlement"; and nearly all the gazetteers and cyclopaedias that $I$ have consulted are equally vague. The "Penny Cyclopaedia," vol. xxi, p. 259 (art. 'Serampore'), says: "The Danes obtained possession of Serampore in 1676"; and the "Gazetteer of the World," " edited by a member of the Royal Geographical Society" (no date), vol. vi, p. 545 (art. 'Serampore'), says: "About the year 1676, the Danes obtained a site here for their factory from the Nabob, Shaista Khan." That the Danish factory at Serampore, or Frederiksnagar, dates from circa 1676 is very probable, for Thaarup, in his "Historiske og Statistiske Efterretninger om det Kongl. octroierede Danske asiatiske Compagnie,"

I Sir Henry Yule considered the insertion of these names as "interpolations," because the map professes to have been compiled "under the direction of Mattheus van der [den] Broucke, who was Directeur of the Dutch affairs in Bengal from 1658 to 1664 " (and died in 1685). But Colonel Yule appears to have overlooked the statement of Valentyn, on p. 160, that the map was the work of different hands at various periods, the latest to add to it being Joban van Leenen (whose name appears on the map). Sir Henry also does not seem to have noticed that the map varies considerably in different copies of Valentyn's work. For instance, in my copy the title is on the left centre, the country is represented as studded all over with hills, and the names of places are very few. On the other hand, the map in one of the British Museum copies (the other copy lacks the map) has the title in the right-hand top corner; rice-fields to a large extent take the place of hills; and the place-names are very numerous (including the so-called "interpolations"). This map also embraces a laryer extent of country. 
p. 30, says: "In the meantime the Company had in 1673 succeeded in coming to an agreement with the inhabitants of Bengal, whereby the protracted hostilities were brought to an end, and the Danes once more came into possession of factories on the Bengal coasts." Thaarup, however, though his summary comes down to the end of the last century, never mentions Serampore; and Valentyn (op. cit., p. 162), writing circa 1725, and describing the various European factories on the Hughli, simply says: "The Danes have here only an ordinary house, two miles lower still than the French factory" (at Chandernagore).-Yours very truly,

Croydon, April 29.

Donald Ferguson.

\section{An Archarological Problem.}

Sir,-In India and beyond the boundaries of it there are many objects of antiquity, the origin and circumstances of the growth of which have yet been obscure to the scholar, and far from being definitely known to the ordinary traveller.

Every summer dozens of European ladies and gentlemen and many eminent Indians pass through the long and everwinding Jhelum Valley Road, with high mountain walls generally on the right and the powerful stream flowing in an almost ever-changing form on the left. Many such travellers must have halied at the Dak Banglow of Rampur, and noticed a very large workshop near it. Just a little higher up from the State workshops, on the right side of the road, is to be found a very large temple built of blocks of well-cut stone of cubical form. The building is of a rectangular form, and having altogether a compact appearance. The height will not be less than some of the noteworthy temples of Brindaban, to which pilgrims and travellers resort by hundreds. There is nothing about the face of it except its immensely tall doorway with a pair of pillars on either side. A balcony or shade, strongly 